\title{
The (re)construction of own identity in nurses' work in Brazil: exploratory study
}

\author{
A (re)construção da identidade própria no trabalho das enfermeiras: estudo exploratório
}

La (re)construcción de la identidad propia en el trabajo de las enfermeras en Brasil: estudio exploratorio

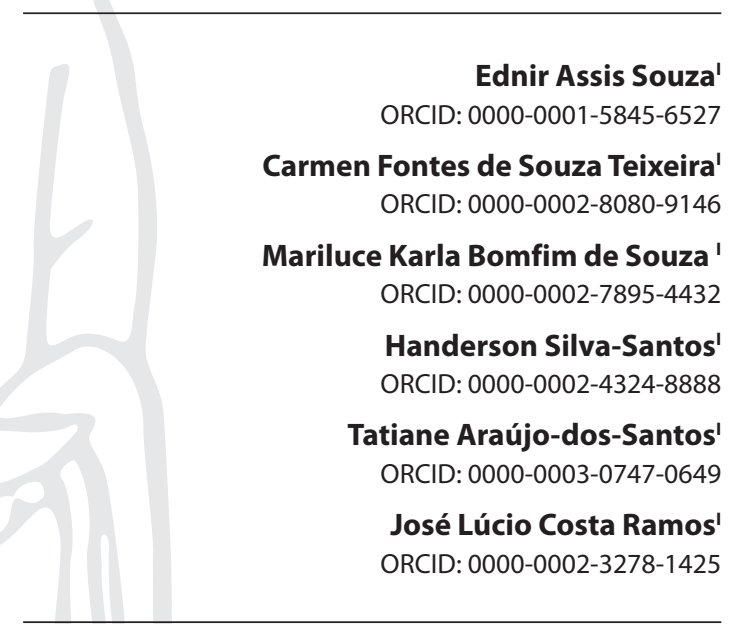

' Universidade Federal da Bahia. Salvador, Bahia, Brazil.

How to cite this article: Souza EA, Teixeira CFS, Souza MKB, Silva-Santos H, Araújo-dos-Santos T, Ramos JLC. The (re)construction of own identity in nurses' work in Brazil: exploratory study.

Rev Bras Enferm. 2020;73(6):e20180928.

doi: http://dx.doi.org/10.1590/0034-7167-2018-0928

Corresponding author:

Ednir Assis Souza

E-mail: ednirassis@hotmail.com

EDITOR IN CHIEF: Dulce Barbosa

ASSOCIATE EDITOR: Rafael Silva

Submission: 04-27-2019

Approval: 11-16-2019

\begin{abstract}
Objective: To analyse a professional trajectory and how identity conformations of a group of nurses in professional practice in Brazil. Methods: Qualitative study that used the in-depth interviews with nurses in professional practice from 1998 to 2014. Seven nurses working in the various organizational areas of the health systems participated and 3 nurses working in educational and research institutions. The narratives were analyzed in the light of Claude's Dubar theoretical framework and the content analysis technique. Results: The findings demonstrate that career choice is associated with employability, giving little identity. The findings demonstrate that career choice is associated with employability, giving little identity. The formative processes contribute to the (re) construction of identity, as they have produced an anticipation of the future trajectory, identification of job opportunities, recognition, prestige and self-esteem. The care dimension gives greater identity to the workers. Conclusion: The study brings important elements for reflection on the determinants that affect the continuous reconstruction of professional identity, in view of the changes that have been operating in the labor market, in vocational training and in the work of nurses. Descriptors: Identification; Work; Nursing; Nurses; Social Desirability.
\end{abstract}

\section{RESUMO}

Objetivo: Analisar a trajetória profissional e as conformações identitárias de um grupo de enfermeiras em exercício profissional no Brasil. Métodos: Estudo qualitativo que utilizou entrevistas em profundidade com enfermeiras em exercício profissional no período de 1998 a 2014. Participaram sete enfermeiras com atuação nos diversos âmbitos organizativos dos sistemas de saúde; e, três enfermeiras com atuação em instituições de ensino-pesquisa. As narrativas foram analisadas à luz do referencial teórico de Claude Dubar e a partir da técnica de análise de conteúdo. Resultados: Os achados demonstram que a escolha profissional está associada à empregabilidade, conferindo pouca identidade. Os processos formativos contribuem para a (re) construção da identidade, pois produziram uma antecipação da trajetória futura. A dimensão assistencial confere maior identidade às trabalhadoras. Conclusão: $\mathrm{O}$ estudo traz elementos importantes para reflexão acerca dos determinantes que incidem sobre a reconstrução contínua da identidade profissional, tendo em vista as mudanças que vêm se operando no mercado de trabalho, na formação profissional e no trabalho da enfermeira.

Descritores: Identidade Própria; Trabalho; Enfermagem; Enfermeira e Enfermeiro; Desejabilidade Social.

\section{RESUMEN}

Objetivo: Analizar la trayectoria profesional y las conformaciones de la identidad de un equipo de enfermeras en práctica profesional en Brasil. Métodos: Estudio cualitativo que utilizó entrevistas en profundidad con enfermeras con práctica profesional de 1998 a 2014. Ha participado siete enfermeras con actuación en los diversos ámbitos organizativos de los sistemas de salud y tres enfermeras que trabajan en instituciones de enseñanza e investigación. Las narraciones han sido analizadas a la luz del marco teórico de Claude Dubary de la técnica de análisis de contenido. Resultados: Los resultados demuestran que la elección profesional está asociada con la empleabilidad, dando poca identidad. Los procesos formativos contribuyen a la (re) construcción de la identidad, ya que produjeron una anticipación de la trayectoria futura. La dimensión asistencial otorga mayor identidad a los trabajadores. Conclusión: El estudio aporta elementos importantes para la reflexión sobre los determinantes que afectan la reconstrucción continua de la identidad profesional, en vista de los cambios que han estado operando en el mercado laboral, en la formación profesional y en el trabajo de las enfermeras.

Descriptores: Identidad Propia ; Trabajo; Enfermería; Enfermeros; Deseabilidad Social. 


\section{INTRODUCTION}

The nurse's work is a social practice since it uses instruments and techniques produced and used in the profession as well as integrating social, political, economic, and cultural issues ${ }^{(1)}$. It is, therefore, in a certain structured historical context that influences the professional trajectory, the organization of work processes, shaping, and reshaping their identity.

Professional identity, according to the theoretical framework of Claude Dubar ${ }^{(2)}$ - on which we this study -, consists of a specific process of socialization, which unites elements such as career choice, training, employment movements, and practices, either within health institutions or in other social collectives. These constant interactive processes derive self-recognition as a professional in successive configurations and reconfigurations of identity.

Thus, the nurse's professional identity is not finished but is related to the context in which the work is developed in a given culture. Thus, the work conditions the construction and reconstruction of social identities, forged by the history of individuals, in the face of continuous socialization processes and linked to the past-present relationship and projection of the future. Therefore, it articulates not only objective constructions of the spaces where practices and social relations are established but also subjective constructions resulting from the different trajectories ${ }^{(2)}$.

From this perspective ${ }^{(2)}$, there is an articulation between two distinct and simultaneous identity processes. The first concerns the attribution of identity in the daily action, that is, in the interaction with other professionals, within the various institutions, leading to variable forms of labels (identity to the other); and the second refers to the actors' incorporation of identity, acts of belonging that claim identity for themselves. Thus, this dual path of identification makes uncertain official definitions ascribed by others (identities to the other), as well as those claimed for themselves and subjected to the recognition of the other (identities for themselves).

These double meanings of socialization derive from the notion of actor defined at the same time by the determinants of action and their trajectories of formation and employment. Thus, identities are not natural and exclusive, but relative denominations, limited to a given historical moment and social context. Therefore, they are social and language constructions in historical processes and symbolic contexts.

The field of nursing, legitimately composed by the professional categories of nurses, nursing technicians, and nursing assistants, consists of a majority of women and similar work activities, even with the adoption of technical and scientific knowledge and the execution of work in the public sphere. The nurse's work faces technical and social division and is characterized by multiple activities in the assistance, managerial, educational, and research dimensions ${ }^{(3-4)}$.

In the history of the construction of the nurse's professional and social identity, the influence inherited by religion and medicine stood out. The movement to turn away from religion produced the rapprochement with technology and medical knowledge and, later, with other fields of knowledge, such as sociology and psychosociology, forming a body of knowledge and gathering knowledge from different areas ${ }^{(5)}$.
In the Brazilian political and social context, new issues emerge for the organization of nurses' work and gain complexity, such as the growing availability of professionals to the market; worsening working conditions with precariousness; the political indication for integration in the work area; unemployment for nurses; undersized workforce; and the existence of cooperatives or nursing work intermediaries ${ }^{(6)}$.

The contemporary transformations driven by the economic and social context have been influencing the nurse's work, both in the technical and scientific aspects, notably with the expansion of knowledge and new technological apparatuses, as well as in the organizational aspects, mediated by the impositions derived from the economic, political and social structure and ideological health services, over time, considering the increase in available positions and the integration of nurses in this labor market ${ }^{(7)}$.

In order to contribute to the debate, we revisited the nurse's work, taking as subjects nurses in professional practice from 1988 to 2014, taking into account the context of implementation of the Single Health System (SUS) and expansion Supplementary Medical Attention System (SAMS) and, in this, the processes of identity (re) construction.

Also, it is necessary to revisit the nurse's work. Although this has undergone multiple transformations in recent decades, little has been produced in the national and international literature on how these transformations have influenced the construction of the nurse's identity, especially in the organizational setting of the health sector in Brazil.

\section{OBJECTIVE}

To analyze the professional trajectory and identity conformations of a group of nurses in professional practice in Brazil.

\section{METHOD}

\section{Ethical aspects}

The study was submitted and approved by the Ethics Committee of the Federal University of Bahia, in compliance with the Resolution 466 of December 12, 2012, of the Conselho Nacional de Saúde (National Health Council).

\section{Type of study}

This study is an exploratory research, with a qualitative approach, focused on the production and analysis of information about the professional trajectory and identity conformation of a group of nurses in professional practice in Brazil.

We constituted two groups of study participants: the first group included nurses in professional practice in the various organizational systems of health systems, selected by indication of the Conselho Regional de Enfermagem da Bahia (Bahia Regional Nursing Council), considering the criteria: permanence in professional activity within the period of 1988 to 2014; and in the assistance, managerial, educational and research dimensions. The second group, in turn, included nurses who work in teaching-research institutions in the area and develop research 
The (re)construction of own identity in nurses' work: exploratory study Souza EA, Teixeira CFS, Souza MKB, Silva-Santos H, Araújo-dos-Santos T, Ramos JLC.

on the theme of nursing work, selected from the main research groups/line of research nursing stricto sensu graduate programs and courses registered in CNPq (National Research Council).

Therefore, to recruit the study participants, we used the technique of snowball ${ }^{(8)}$, in which the first nurses invited to participate indicated other nurses who, in turn, indicated others and successively. Then, reference chains were formed, in a kind of network, until the "saturation point" was reached, that is, the new interviewees started to repeat the contents already obtained in previous interviews, without adding new relevant information to the research. Thus, the final number of ten participants is justified.

\section{Data Collection}

The data were produced from March to July 2016, using indepth interviews, unstructured, which allowed the free expression and interpretation of the object through information gathered from the nurses' narratives.

We used an interview script containing a single open topic, allowing the individuals to narrate their professional career based on guidelines: the motivation for choosing the career, the characteristics of the educational process, the employment movements, and the professional practice.

The interview script was applied in Salvador, Bahia, Brazil, and in different ways: in-person (at an interviewee's scheduled location), via Skype, and over the phone. The interviews were audio-recorded and lasted an average of 90 minutes.

The collected data were transcribed and arranged in the Excel matrix, in line with the analysis categories proposed in the adopted theoretical framework.

\section{Data Analysis}

The narratives obtained were transcribed, treated and analyzed in order to allow systematic cataloging, based on the categories of analysis defined from adopted the theoretical framework by Claude Dubar ${ }^{(2)}$ and following the objectives of the study. So, we constructed a matrix containing excerpts of the transcripts of the interviews conducted with each group of nurses regarding aspects of their professional careers. Therefore, the conceptions corresponding to the "motivations for professional choice," an expression of the interviewees' subjectivity, were articulated with the categories related to "professional development" "employment movements," and "professional practice" (2). Thus, the findings were organized and analyzed according to the following categories: a) Motivations for professional choice; (b) characteristics of professional development; c) Employment movements; and d) Perceptions about the practice.

\section{RESULTS}

The results are presented based on the nurses' narratives, according to their characterization by a group of interviewees. The first group included 7 nurses with ages ranging from 52 to 63 years, with an average of 33 years of professional practice in the various organizational settings of health systems, from 1988 to 2014. The second group, in turn, included 3 nurses with ages ranging from 52 to 59 years and an average of 35 years of professional practice in teaching-research institutions.

\section{Motivations for career choice}

Among the motivations reported by the first group of interviewees is the affinity for health, aroused by the fact that they had taken vocational-technical courses before graduation. Interest in this area also appears related to the professions such as medicine, dentistry, and physiotherapy, and the final option for nursing was, for example, the socioeconomic conditions that limited professional choices:

I wanted to study dentistry. (N4)

I chose to go to medical school, actually, but I didn't pass the exam. Either I passed in the admittance exam or returned to the small-town life. (N5)

Two interviewees pointed out a particular interest in nursing at the time of professional choice. The professional image, in this case, was built from the previous contact with the work in nursing, establishing a connection between what was seen and what was intended to be:

Before taking the admittance exam, I tried to know what was nursing. (N3)

I have always tended to pursue the health care field, and the nursing work has always enchanted me. (N6)

There are still motivations resulting from experiences lived in childhood, illness of family members that implied the assumption of responsibilities for the care, reinforcing the socially attributed role to women as caregivers:

A natural tendency for wanting to take care. [...] I remember my father when I was born he was already old. [...] He had herpes zoster. I was 9 years old! [...] I think that was unforgettable. (E4).

I intended to take care. (N3)

For the interviewees of the second group, the affinity with the health area was not remarkable. The nurses reported interest in several areas of knowledge, and the choice for the health area and the nursing course, in particular, seems to have been a secondary option:

My teachers said I should follow some exact science career because I was good at math. But I also liked biology. (N8)

I was a very curious young woman interested in the field of arts and letters. I thought of a healthcare option in the field. (N9)

Besides, these interviewees revealed that the objective economic conditions, experienced at the time, interfered in the professional choice, especially regarding the prediction of future employability, and this factor is decisive for the choice of the nursing course: 
The (re)construction of own identity in nurses' work: exploratory study Souza EA, Teixeira CFS, Souza MKB, Silva-Santos H, Araújo-dos-Santos T, Ramos JLC.

I had to go to a public college and here in my city. I began to think about nursing, [...] without knowing very well what it was or not. (N8)

We lived with a very strict financial regulation. I couldn't afford to lose my college admittance exam and wanted something that could give me a job. (N9)

In both groups, there is mention of the need for integration in the labor market as the preponderant factor for professional choice, combined with affinity with the health care area. In the second group, the choice for nursing was circumstantial, since the interviewees did not reveal any identification with the work in this field. Noteworthy is the scarce reference to previous contacts or even inspiration in public figures of nurses.

\section{Characteristics of professional development}

The enrollment in a vocational course represents one of the fundamental theoretical elements for the understanding of nurses' professional career. This study investigated this aspect taking into account the year of graduation, the nature of the higher education institution where the course was held, as well as the other qualifications the interviewees acquired throughout their careers.

In both groups, the period in which the interviewees graduated varied from 1978 to 1986 . Only one of the interviewees graduated from a private university. All have some type of specialization, and in the first group, only two have a master's degree, and one was pursuing a doctorate at the time of the interview. This fact differs from that found in the second group, in which nurses act as teachers in public universities and all have a master's and doctorate.

Regarding the areas of knowledge and work, in the first group, five interviewees were engaged in hospital activities, with three of them linked to care; and two to management. In the second group, it is observed that the affiliation to the public / collective health area is predominant, expressed in the choice of postgraduate courses at the master and doctorate level.

\section{Employment Movements}

The integration in the labor market implies the confrontation between the learning developed during the formation process and the reality of the health services. In the first group, this insertion occurred mainly in-hospital care services (philanthropic and private):

My first health unit as a nurse was the philanthropic hospital. (N1)

I was soon entering the hospital activity in the private care system. (N4)

The hospital area meant opportunities for integration in the labor market for these interviewees. Following the insertion in the labor market, there was a continuous process of displacement of these nurses to other work experiences. The main reason for interinstitutional displacement is the selection for a public working position:

After working in several private hospitals, I applied for the university and went to the University Hospital. (N4)
In 1989, I was selected for a public position for the State Department of Health. I went to a general hospital. Always parallel to other professional experiences. (N7)

There is also a change in the scope of hospital care to other levels of care, motivated by factors associated with affinities with work dynamics or the clientele assisted and the establishment of permanent employment relationships:

I preferred to go to the Basic Unit to meet people and do a job that I liked best. ,35Already in the public service, I worked in several Basic Units. (N2)

I did not want to work in hospitals anymore. My focus was on working with communities since the beginning. It was something I wanted. (N3)

Regarding the current employment, almost all nurses are in public institutions, with permanent links, a fact that is justified in public positions, as well as in the legal changes envisaged in the 1988 Constitution, as regards the compulsory amendment of the ordinary labor legislation into the civil service legislation:

I continued in the Community Health Center [PSF] because I was linked to the city hall and the state. (N3)

When I started at the State Department of Health, everyone worked under the ordinary labor legislation [...] later we became under the civil service legislation. (N6)

Only one of the interviewees in this group chose to stay in a private institution, adhering to the organizational mechanisms offered to reduce the staff of public institutions.

In the second group, the training was crucial to initiate the first job opportunities, which is characteristic of this group, the professional qualification before entering the labor market. The formative trajectory, while contributing to a more privileged competitive situation in the selection processes, provided some recognition, culminating in personal invitations to perform specific activities:

I specialized in Mental Health and applied to a selection process. Approved, I worked at a university psychiatric hospital for three years. (N10)

When I finished the specialization, I was invited by a teacher at the School of Nursing to be a preceptor in nursing training from the Secretaria de Saúde do Estado [State Department of Health]. (N9)

In addition to training, employment movements were marked by approval in various selection processes, whose contractual links were characterized by temporary and precarious aspects:

There was no exam. The Department of Health did not have exams for selection processes, but it was always hiring for training projects. I did several of them. I was selected and was hired via CLT [ordinary labor legislation], working on the books, for the first time. (N9)

It is notorious that teaching and research practices marked the varied professional experiences resulting from these selection processes, a fact that seems to be associated with the option for teaching: 
The (re)construction of own identity in nurses' work: exploratory study Souza EA, Teixeira CFS, Souza MKB, Silva-Santos H, Araújo-dos-Santos T, Ramos JLC.

Due to my connection with the work at the School Health Center, the School of Nursing's presence has always been very important. (N8)

[I did] go to university to see what it was like if I identified a little with that. (N9)

With my experience, I would have contributed and could continue to develop myself in research, but no longer as a teaching and research support technique, but as a professor. (N10)

\section{Perception of professional practices}

Professional practices relate to the performance of a category and thus give a distinction to a particular group of professionals. Interviewees in the first group tend to emphasize the care dimension, even when their daily practice includes other dimensions, such as managerial, educational, and research. This fact is not limited only to hospital care:

I was that nurse who provided the most care, did the nursing care management process with respect for the technicians. (N1)

At the time, the hospital was (called) the Social Medical Unit. The nurse had to coordinate everyone. I really had to assist. (N3)

In the Basic Unit, I was responsible for all nurse activities. The Health Center as a whole because it had no director. So we were responsible for the administrative and the assistance. At the time, we called it Public Health. (N6)

The practices related to the care dimension of the nurse's work encompass activities that are not part of the scope of action, however, due to the absence of professionals who were responsible for their execution, the nurses themselves performed them:

We collected blood samples for the blood gas test, put it in the machine. We learned to analyze the blood gas test, prescribed physical therapy care. We had no physical therapists and understood that this was our job. (N4)

On the other hand, even when such activities were recognized as part of the nurse's work and technical nature, the interviewees considered them unusual and therefore did not value them as part of their work:

We did everything with great skill and safety. [...] Who pushed the bed into the room to pass the probe was the nurse, not the technician. [...] Nonsense in relation to what we se here in the hospital. [...] The nursing technician, who was then assistant, was the one who controlled the material. And the nurse there, doing everything. Giving full care, as people say. [...] It was really manual labor. (N7)

Such testimonies lead to thinking of the blurring of boundaries between the nurse's scope of action and the nursing technicians and assistants. In the first example, the interviewees are surprised to have to "make decisions"; and in the second example, they resent doing "manual labor."This ambiguous perception highlights the nurses' own difficulty in clearly defining the purposes of their work and the scope of their activities.
In the area of primary care, the care dimension is associated with clinical practice, aimed at nursing consultation and other actions - previously exclusive to medical professionals and currently accepted now to nurses, as provided for in the various programs implemented by the Ministério da Saúde (Department of Health):

Today, they include nursing consultations in all programs, conducting preventives that were previously exclusive to doctors. (N2)

Regarding the managerial dimension, this practice seems to be clearly perceived when associated with supervisory, managerial, or other positions contained in the institutional hierarchy and detached from the assistance dimension:

I was the supervisor of other units: medical clinic, surgical clinic, and pediatrics, and then I headed the nursing service. I spent a period as a health care manager. (N1)

The perception of the educational dimension is clear. There is a distinction between this dimension and the others, and its presence in more than one health care scope. However, in this group, the nurses seem to understand the educational practices as little stimulating and detached from the research dimension:

I went to a private hospital, [...] it was like a school. It was my first contact with students. I worked with the education of nursing technicians. I taught theory and practice. At the emergency service [SAMU], I had two phases: one giving assistance in public roads and one where I was an instructor. They the nursing technicians were tested: 'Lost? Come back! Do training! ' [...] It got boring because I was just an instructor. (N7)

In the second group, although the interviewees present trajectories that portray little insertion in the activities related to direct assistance, they perceive the assistance dimension of the work as the activities foreseen in the scope of the government programs, as well as performed, particularly, in the scope of primary care, in which it is possible to highlight the nursing consultation:

I did some actions in the City Hall programs, such as care, nursing consultation, and family planning counseling. (N8)

Regarding the managerial dimension of work, the actions performed when detached from positions belonging to institutional structures seem to be perceived as complementary to those performed in the assistance dimension, which is contrary to the first group:

In addition to these activities as a nurse, indirect care of patients and families, I also provided facilities for administration, management of unit material and work.. (N10)

The educational and research dimension, in contrast to the first group, was perceived as complementary and not dissociated, both regarding the work processes related to training and management assistance. It is possible to explain this fact by the trajectory of this group of interviewees, which included constant approximations with the teaching and research dimensions: 
The School Health Center was also a Teaching Unit. I was hired as a nurse, not only for care but also to be directly involved in teaching and research activities. (N10)

\section{DISCUSSION}

The findings of this study indicate that the possibility of employability largely determined nurses' professional choice. This aspect was fundamental for the professional choice in both groups, as the interviewees aspired to a professionalization that provided the development of their potentialities, which seems to break, in a way, with references from the sexist stereotype ${ }^{(5-10)}$. In this sense, the identity of oneself as "servile" and "devoted" pointed out by other studies (11-12), which analyzed the reasons for professional choice for nursing, was not expressed in both groups analyzed. On the contrary, according to the findings shown here, the option for nursing represented a strategy that guaranteed the achievement of financial autonomy and freedom, which seemed possible given the difficulties of entering other courses, such as physiotherapy and medicine.

About the training, there seems to have been, in both groups, the search for specific knowledge through specialization (lato sensu), which prevail over other postgraduate courses (stricto sensu), since all nurses have titles of specialists in some area of knowledge. Graduation represents, therefore, a minimum condition for the conformation of professional identity, whereas the subsequent formative itinerary, when associated with the integration in the labor market, seems to be the identity element par excellence, because it implies the appropriation of competencies that allow the nurses a more favorable position in the construction of their careers, vis-à-vis the adequacy to the objectives of the institutions ${ }^{(2)}$.

It is noteworthy that these specializations were to the hospital area and, only more recently, began to include primary care. This fact derives from the very organizational dynamics of the Brazilian health system, which has been undergoing a reform process that contemplates the expansion of the basic service network ${ }^{(7,13)}$. The fact that there are only two female interviewees in the health services who have stricto sensu postgraduate training may be associated with the respective career plans of the institutions to which they joined, which favor the other levels of training for functional progression.

From the above, training can be considered a way to broaden knowledge and skills and even a stimulus for a job change, since the knowledge acquired enables them to other activities, whose accomplishment brings greater satisfaction. On the other hand, the acquisition of knowledge and skills through the formative process can also contribute to an awareness of professional ${ }^{(2)}$ belonging, in which a set of values emerges. This matter fosters a professional attitude that values integration in a given institution, in order to consolidate bonds and discourage mobility initiatives.

Therefore, it is possible to notice that training contributes to the conformation of self-identity as a future expression and also identity to the other ${ }^{(2)}$, producing anticipation of the future trajectory that guides the identification of job opportunities that can ensure recognition, prestige, and self-esteem ${ }^{(14)}$.

Judging by the results obtained in this study, the nurses' professional career is dynamic and follows, to a certain extent, the process of reorganization of health systems in Brazil in recent decades, marked by advances and setbacks in the construction of SUS, while expanding the private service network ${ }^{(7,15)}$.

Thus, we found that following the first employment movement there was a mobility of the nurses in the labor market, a process determined by several factors, namely: the selections in public positions that motivated displacement to other institutions and sometimes the option to move to other levels of health care, particularly primary care. These displacements also occurred due to unfavorable working conditions or individualized invitations to perform certain activities, mostly due to the qualifications acquired in postgraduate courses, which allowed the inclusion of nurses in teaching practices or management.

In a study of graduate nurses (from 2006 to 2012) of the University of São Paulo School of Nursing ${ }^{(16)}$, about their immersion in the labor market, it was found that the selection process was the main entry in the first 3 jobs, followed by the public positions, with the indication of colleagues, the third form referred by little more than $10 \%$ of the graduates. A study on nursing graduates from the Federal University of Santa Catarina also mentioned these forms of admission ${ }^{(17)}$. Therefore, it is noteworthy that such results reveal differences in the insertion in the labor market by more recent graduating groups when compared to the narratives of the nurses participating in this study, whose formation dates back to more than a decade.

Despite these shifts, it is noteworthy that the interviewees revealed interest and willingness to remain in employment, seeking to establish stable employment relationships. Such stability is not only due to an administrative connection but is related to the integration in workplaces where they can exercise their competences and ensure recognition by their peers. Thus, the space of recognition of nurses in both groups of respondents seems to privilege the concrete work situation achieved: the position and allocation in production units where they can develop practices for which they feel able.

Regarding the perception about the practices, it was possible to identify that the activities understood by the interviewees as assistance are, in fact, managerial, a fact that seems unclear notably in the first group. Paradoxically, the activities considered as inherent to the care dimension do not seem to give nurses a proper identity, since such activities, in the technical division of nursing work, are the responsibility of the technicians and assistants, or even some of these, when performed by nurses, are inherent in the scope of action foreseen for other health professions. In this way, the "acts of attributions," based on the socially constructed image of the nurse's work and centered on the care dimension, are confronted with the "acts of belonging," which are based both on the competences arising from the formative processes and on the " knowledge of organizations, "which, based on internal interests, imprint a logic on the work of the nurse.

Regarding the managerial dimension, it is important to highlight that this is a non-dissociable function of care activities, because nurses are responsible for managing the work processes of the nursing team and other professionals, whether in the hospital, whether in primary care units. This inseparability of care and management performance is the main characteristic of the nurse's work in Brazil ${ }^{(1,4,18)}$, which is the dimension that gives greater 
The (re)construction of own identity in nurses' work: exploratory study Souza EA, Teixeira CFS, Souza MKB, Silva-Santos H, Araújo-dos-Santos T, Ramos JLC.

identity to professionals, even though such activities are more clearly perceived when related to the functions resulting from the occupation of positions foreseen in the institutional hierarchy.

By denying the double care-managerial dimension of their work, nurses project the care dimension of their work as an objective image, reproducing ideologized conceptions that weaken their understanding of their own work and consequently their professional identity, since this dimension is predominantly imposed on them by the labor market.

The educational dimension, for the group of nurses working in health institutions, confers little identity to professional work and, when mentioned, is perceived by some of the interviewees as unattractive, monotonous and discouraging activities, even when related to continuing education of the nursing staff or health education practices aimed at individuals, families and the community.

We observed the lack of research activity in the daily lives of nurses in the first group, which may be related to the lack of encouragement or lack of partnerships with teaching-research institutions, which commonly use health services as a space for research practices. Thus, although health services are objects of investigation that can be analyzed from different angles, the study points to the distance of these nurses from the dimension of research and knowledge production, as well as technological production. About this, the study by Püschel et al. ${ }^{(16)}$ corroborates these findings, since higher and vocational education has the lowest occupancy when compared to insertion in care spaces, with hospitals in the first position, followed by the Basic Health Units.

For the second group, however, the teaching and research dimensions confer greater identity and are perceived as inseparable, which can relate to the professional trajectories of these interviewees, which remarkably contemplated the two dimensions mentioned.

\section{Study Limitations}

It is worth discussing the limits of the methodology used in this study. Even with the care taken during the process of choosing the interviewees, seeking to compose a group that represents the diversity of professional profiles of nurses who have worked in the labor market for more than two decades, this may not express the diversity that may exist in the universe of professionals, especially in such a large country and with such different realities as is the case of Brazil.

\section{Contributions to the field}

The analysis of the processes of configuration and identity reconfiguration along the respective professional trajectories, in the context of SUS implementation and SAMS expansion, conforms to the central problem that guides this study. Therefore, the relevance of these questions can be considered for the nursing scientific field and for the practical field of work that health services and systems have been developing, in which the participation of nurses is significant.

By revealing which factors are present in the nurse's configuration and identity reconfiguration, this study contributes to the scientific knowledge in the field of nursing work studies. It is possible to apply such knowledge in the formative processes and the organization of professional practice for the cohesive and vigorous construction of professional identity.

\section{FINAL CONSIDERATIONS}

It is important to emphasize, at this time, the power to reconstruct the nurses' professional career, identifying the elements that constitute this process, such as motivation for professional choice, characteristics of undergraduate and graduate education, the employment movements and the perception about the practices carried out professionally in the health and teaching-research institutions.

Considering the analysis of these elements, the study reveals that the professional choice motivated by employability points to the lack of knowledge and little identity with the nurse's work. Thus, it was the postgraduate training processes that most contributed to the reconfiguration of this identity as they produced anticipation of the future trajectory (self-identity) that guided the identification of job opportunities, recognition, prestige, and self-esteem (identity to others). Regarding practices, the care dimension has given these workers greater identity, although the nature of their work is eminently care-management. This denial of nurses' double care-management dimension weakens their understanding of their work, causing conflicts and consequences for the construction of professional identity.

Further research we recommended to deepen the analysis of the aspects indicated here, indicated, in order to continue the study of the process of construction/reconstruction of nurses' professional identity, taking into account the political, economic and social scenario as well as its consequences for the health system in the country and new generations of nurses.

\section{REFERENCES}

1. Fernandes MC, Silva LMS, Silva MRF, Torres RAM, Dias MSA, Moreira TMMM, et al. Identity of primary health care nurses: perception of "doing everything". Rev Bras Enferm. 2018;71(1):142-7. doi: 10.1590/0034-7167-2016-0382

2. Dubar C. A socialização: construção das identidades sociais e profissionais. São Paulo: Martins Fontes; 2005. 240 p.

3. Palácio do Planalto (BR). Casa Civil Subchefia para assuntos jurídicos. Lei 7.498 de 25 de junho de 1986. Dispõe sobre a regulamentação do exercício da enfermagem, e dá outras providências [Internet]. Brasília, DF: Casa Civil, 1986[cited 2018 Sep 20]. Available from: http://www. planalto.gov.br/ccivil_03/leis/L7498.htm

4. Leal JAL, Melo CMM. The nurses' work process in different countries: an integrative review. Rev Bras Enferm. 2018;71(2):413-23. doi: 10.1590/0034-7167-2016-0468 
The (re)construction of own identity in nurses' work: exploratory study

5. Almeida DB, Queirós PJP, Silva GTR, Laitano ADC, Almeida SS. Sexist stereotypes in portuguese nursing: a historical study in the period 1935 to 1974. Esc Anna Nery[Internet]. 2016 [cited 2018 Aug 30];20(2):228-35. Available from: http://www.scielo.br/pdf/ean/v20n2/1414-8145ean-20-02-0228.pdf

6. Oliveira JSA, Pires DEP, Alvarez AM, Sena RR, Medeiros SM, Andrade SR. Trends in the job market of nurses in the view of managers. Rev Bras Enferm. 2018;71(1):148-55. doi: 10.1590/0034-7167-2016-0103

7. Souza EA, Teixeira CF, Souza MKB. Análise da produção cientifica nacional sobre o trabalho da enfermeira (1988-2014). Saúde Debate. [Internet] 2017 [cited 2018 Nov 06];41(113):630-46. Available from: http://www.scielo.br/pdf/sdeb/v41n113/0103-1104-sdeb-41-113-0630.pdf

8. Vinuto J. A amostragem em bola de neve na pesquisa qualitativa: um debate em aberto. Temáticas [Internet]. 2016[cited 2018 May 10];22(44):203-20. Available from: https://www.ifch.unicamp.br/ojs/index.php/tematicas/article/download/2144/1637

9. Bardin L. Análise de conteúdo. São Paulo: Edições 70; 2011. 229 p.

10. Escobar L. O sexo das profissões: gênero e identidade socioprofissional em Enfermagem. Porto: Afrontamento; 2004.160 p.

11. Ribeiro AAA, Falcon GS, Borenstein MS, Padilha MICS. Professional choice and the social imaginary - Brazilian and Peruvian nurses. Esc. Anna Nery [Internet]. 2006 [cited 2018 Oct 17];10(2): 241-50. Available from; http://www.scielo.br/pdf/ean/v10n2/a11v10n2.pdf

12. Barlem JGT, Lunardi VL, Bordignon SS, Barlem ELD, Lunardi Filho WD, Silveira RS, Zacarias CC. Opção e evasão de um curso de graduação em enfermagem: percepção de estudantes evadidos. Rev Gaúcha Enferm[Internet]. 2012[cited 2018 Oct 10];33(2):132-8. Available from: http:// www.scielo.br/pdf/rgenf/v33n2/19.pdf

13. Machado MH, Oliveira ES, Lemos WR, Lacerda WF, Justino E. Mercado de trabalho em enfermagem no âmbito do SUS: uma abordagem a partir da pesquisa Perfil da Enfermagem no Brasil. Divulg Saúde Debate [Internet]. 2016[cited 2018 Aug 30];56:52-69. Available from:http:// cebes.org.br/site/wpcontent/uploads/2016/12/Divulga\%C3\%A7\%C3\%A30_56_Cofen.pdf

14. Ferreira AG, Henriques HMG. A constituição da profissão dos enfermeiros em Portugal: A Escola de Enfermagem de Castelo Branco (19481988). Rev Educ Questão[Internet]. 2013[cited 2018 Oct 10];45(31):7-34. Available from: https://periodicos.ufrn.br/educacaoemquestao/ article/view/5101/4086

15. Alves SMC. Avanços e retrocessos do direito à saúde no Brasil: uma análise crítica. Cad Ibero-Amer Dir. Sanit [Internet]. 2016 [cited 2018 Oct 30];5(4):186-94. doi: 10.17566/ciads.v5i4.340

16. Püschel VAA, Costa D, Reis PP, Oliveira LB, Carbogim FC. Nurses in the labor market: professional insertion, competencies and skills. Rev Bras Enferm. 2017;70(6):1220-6. doi: 10.1590/0034-7167-2016-0061

17. Jesus BH, Gomes DC, Spillere LBB, Prado ML, Canever BP. Job market placement: professional trajectory of nursing graduates. Esc Anna Nery. 2013;17(2):336-45. doi: 10.1590/S1414-81452013000200019

18. Oliveira JLC, Toso BRGO, Matsuda LM. Advanced practices for care management: reflections on the Brazilian Nursing. Rev Bras Enferm. 2018;71(4):2060-5. doi: 10.1590/0034-7167-2017-0115 